\title{
REMOTE JOB DESIGN POSSIBILITIES TO WORK IN LITHUANIAN COMPANIES FROM DISTANT LOCATIONS
}

\author{
*Sonata Staniuliené, Justinė Jurova \\ Vytautas Magnus University, Lithuania \\ *Corresponding author's email: sonata.staniuliene@vdu.lt
}

\begin{abstract}
The study examines literature on remote job design possibilities from distant locations. After the remote job design concept is formed, the premises for the use of remote job design are analysed, the necessary conditions, possibilities, and employees' willingness to work remotely are explained, summarizing the advantages and disadvantages of remote work. The quantitative research was conducted to reveal out the possibilities of remote job design in Lithuanian companies according to the areas of work in which it is possible, impossible to work remotely or possible to work flexibly. The willingness to do remote jobs was also examined, and the picture of prone to remote job employee by demographic characteristics of the respondents was drawn. The most convenient distant locations, informational and communication technologies (ICT) and addresses of indirect communication were identified. It was found that survey participants are not resistant to work remotely, and it also showed that at least partially remote job could be designed in majority of Lithuanian companies. Most of them prefer flexible mixed variation of remote and traditional work. The main difficulties were named that required high level of self-discipline, but not the lack or deficiencies in using ICT, electronic devices and designing other required conditions for remote job design.
\end{abstract}

Key words: job design, remote work, distant locations, Lithuanian companies.

\section{Introduction}

The trends of globalization, growth, and acceleration of quality of life, emergence of knowledge society and economy, growth of population mobility and evolution of informational and communication technologies (ICT) lead to the emergence of remote job design concept. These days the pandemic situation is fostering remoteness of jobs over the world.

Remote job design reveals its benefits in a global environment, where it is possible to work remotely in the same country, as well as to successfully collaborate with foreign companies from distant locations using ICT. Remote job design enables an organization to hire the best professionals and global talents regardless of where they live. Remote job design is also useful for developing activities in another country without living there. As technology for the transfer of required information speeds up, more attention can be paid to reduce the cost to both employers and employees and increase benefits from innovations in possible remoteness of operations. In order to solve the problems of geographical distance, avoid high costs and save time for the company's employees, companies have to be flexible, use ICT and take advantage of the remote job design.

Before the pandemic Covid-19 situation, Gallup (2017) report stated that about $37 \%$ workforce in the USA worked remotely. According to Eurofund (2017), $17 \%$ of employees worked remotely in the EU, with Denmark having the highest number of teleworkers (37\%). In Lithuania, only about $13 \%$ of workforce worked remotely, and the highest prevalence of such workers is recorded in the telecommunications and information technology services sector. According to a Cvmarket.lt (2017), 60\% employees in Lithuania showed willingness to work remotely and only $13 \%$ did not want remote work because they liked to to go out and be in the society. During the pandemic, $61 \%$ workers were given the opportunity to work remotely, and only $34 \%$ workers indicated that the nature of their job did not allow them to work remotely (Kantar, 2020).

It is interesting to acknowledge what possibilities are to transfer jobs to a distance without compromising the performance of job functions, which during the pandemic could have been ignored due to the need to keep distance and avoid contact. The question also arises what proportion of the jobs may be at least partially remote or are not suitable for remote job design, and what part of jobs have opportunities to work from a distant location in the future. In order to design remote jobs in Lithuanian companies, it is necessary to find out the current perception of the benefits of remote work and its use in Lithuanian companies. The current situation or expectations may differ depending on the field of work, the size of the company, the position held in the company, the gender and age group of the employees of the companies.

Existing knowledge on remote job design can be questioned in an extraordinary pandemic context. Recently a number of studies analyse remote work, telework, telecommuting (Choudhury, Foroughi, \& Larson, 2021; Wang et al., 2021; Gallacher \& Hossain, 2020; Gigi \& Sangeetha, 2020; Walenetek, 2020; da Silva Abbad et al., 2019; Charalampous et al., 2019; Kaduk et al., 2019; etc.), but still there is a lack of studies relating remote job design to possibilities of work from distant locations. Due to the mentioned reasons, further research is needed to solve the research problem - what are possibilities of remote job design in Lithuanian companies working from distant locations? Thus, the object of the research is remote 
job design in Lithuanian companies from distant locations, and the aim of the research is to analyse the possibilities of remote job design in Lithuanian companies from distant locations. To achieve this goal, the following objectives have been set: (1) to perform the analysis of scientific literature on remote job design; (2) to analyse the possibilities of remote job design in Lithuanian companies from distant locations by conducting an empirical research.

Research methods used in the paper are analysis of the scientific literature and quantitative method of survey.

\section{Materials and Methods}

With the advent of telecommunication, internet technologies, and increased knowledge work, organizational leaders should question the old, hierarchical notion of job design (Greve \& Salaff, 2008). Remote work leads to a new form of job design in which task settings work differently. Due to certain opportunities of globalization and innovations, modern organization has more opportunities to work remotely.

The variety of terminology describing work in a distance from the workplace, the great variety of definitions of remote work in the scientific literature make it difficult to examine the problem of remote work. Still, it was found as a broader term comparing to telework (performed by ICT but could be from traditional office) or telecommuting (from a distant location, but not necessary by ICT). Nevertheless, based on the analysis of the scientific literature, the essential features of this form of work organization have been identified. In all definitions of remote work (Konradt, Schmook, \& Malecke, 2000; Fonner \& Roloff, 2010, etc.) common features could be found: (1) the dispersion of the geographical location of the members of the organization, (2) lack of face-to-face communication, and (3) the dependence on electronic devices and ICT. The classification of the ways to design remote job allows to be broken down into types according to the place of work, time allocation and intensity of use (Grinceviciene, 2020). Similarly, Haddon \& Brynin (2005) point out that remote work is not a homogeneous derivative, and therefore it is necessary to design it by the individual elements of diversity of workplace, time, and scope. For clarity, Gajendran \& Harrison (2012) and Perez Perez, Sanchez \& de-Luis (2003) describe the intensity of remote work use in terms of periodicity, distinguishing between full-time, partial, and ad hoc remote work. Though, Garrett \& Danziger (2007) divide work locations into three categories: (1) flexible work in the office and at home, (2) work at a fixed location (home or other scheduled in employment contract location), or (3) mobile work when working in an undetermined place of work (traveling, hotels, etc.).
As remote job could be designed only using ICT (Grinceviciene, 2020; Walentek, 2020), many scholars list commonly used e-communication channels: e-mail, video, and audio conferences (meetings), messages, forums, specific software, etc. (Karis, Wildman, \& Mane, 2016).

Many benefits of remote work from the employee's point of view make it possible to design in the companies (Grinceviciene, 2020; Walentek, 2020; Choudhury, Foroughi \& Larson, 2021; (Morganson et al., 2010; Gigi \& Sangeetha, 2020; Avdeeva, Davydova, \& Shulgin, 2020): the possibility to earn higher salary working for high salaried country's company, to save time and money due to the elimination of commuting and business trips, the possibility of living in a place far away from the company's base, flexibility of work named work-from-anywhere, flexibility in scheduling work, less stress and more comfortable working conditions, high level of work-life balance support, and greater employees' job satisfaction.

Designing of remote jobs for the companies would reduce the company's operating and real estate costs (Choudhury, Foroughi, \& Larson, 2021), lead to increased productivity (Gajendran \& Harrison, 2012), retain good employees when their living conditions change, and hire the best professionals (Duoba, 2009), encourage knowledge-based working by ICT and then receive a higher income (Sarkiunaite \& Gaputiene, 2006).

Nevertheless, many scholars argue that remote workers recognized less decision-making autonomy, task variety, task significance, task identity, job complexity, problem solving, and specialization than the traditional employees (da Silva Abbad et al., 2019), experienced threats in professional advancement (Charalampous et al., 2019), over-working and a lack of time for recuperation (Grant, Wallace, \& Spurgeon, 2013), work-home interference, ineffective communication, procrastination, and loneliness (Wang et al., 2021), a sense of social exclusion (Gibson \& Gibbs, 2006), ambiguous perception of information by ICT (Derks \& Bakker, 2010), lack of nonverbal behaviour related to different national language, culture and technologies (Duarte \& Snyder, 2006).

One more issue concerning remote job design is the legal status of remote work. When companies have been calling employees back to the office, some employees are therefore asking to continue remote arrangements their employers adopted when forced to close. Should an employer refuse, the affected employee will have to balance legitimate fears for safety and job (Arnow-Richman, 2020). This differentiation between voluntary and forced scheduling and remote work underlines the complexity of flexible scheduling and remote work, especially among white-collar, salaried professionals (Kaduk et al., 2019). 
Implementing remote job design, planning and thorough scientific analysis should be performed. In order to determine the possibility of remote job design in a company, it is necessary to answer important questions about geographical location, interdependence of companies, company's uniqueness, competencies, level of trust and use of ICT in the company (Duoba \& Savaneviciene, 2010). Benefits and barriers should be considered as well, leveraging the right level and mode of remote job design in particular circumstances.

Many managers are afraid to lose control and diminish organizational capacity for innovation due to decreased collaboration (Calvo, 2010). Managers must be trained to maintain remote working relationships and secure productivity (Calvo, 2010). Formulation of work goals, adaptation, and motivation of remote employees improve communication between employees (Sarkiunaite, 2009). Trust and management style were found to be key influences on remote worker effectiveness (Grant, Wallace \& Spurgeon, 2013). Remote work candidates should be selected through psychometrically validated criteria. After all, remote workers must be assessed fairly and objectively on the accomplishment of their work (Calvo, 2010). Both readiness from employer and employee are considered as the main factors to implement remote job design in the companies successfully (Duarte \& Snyder, 2006). Methods

Quantitative research was chosen for data collection, which aims to obtain quantitative information about a large number of research objects (in this case, persons working in Lithuanian companies). The research questionnaire consists of an introductory part, demographic questions, and questions about features, preferences, extent, and possibilities of virtual job design in the companies. Willingness and ability to work in remote locations, the application of remote job design according to the respondents' field of occupation, commuting and other costs, as well as benefits and barriers (in scale from 1 to 3 ) when working remotely were screened.

The research sample was calculated on the basis of Paniotto formula (Kardelis, 2002). According to the data of the Department of Statistics of Lithuania, in the $3^{\text {rd }}$ quarter of 2019 , there were 1378.1 thousand persons who were working in any job and receiving remuneration in money). The selected sample error size is $7 \%$. Calculations show that 204 respondents need to be interviewed to ensure the representativeness and reliability of the survey, the survey involved 211 respondents working in various Lithuanian organizations; therefore, it can be stated that the results of the survey are reliable.

Participants were sent an invitation e-mail with a link to fill the online questionnaire.

$66.4 \%$ of respondents were woman and $33.6 \%$ men; $69.7 \%$ are $16-25$ years old, $23.7 \%-26-35$, and $4.3 \%-36-45,1.9 \%-46-55$, and $0.5 \%$ is older than 56 respectively; $17.5 \%$ are working in sales, $11.8 \%-$ service, $9 \%$ - marketing/advertising, $8.1 \%$ - production, $7.1 \%$ - culture/arts/entertainment, $7.1 \%$ - tourism/ catering. $15.6 \%$ were employers/entrepreneurs, $8,1 \%-$ self-employed, and 76.3\% - employees; $33.6 \%$ work in micro-enterprises, $29.4 \%$ - small, $19.9 \%$ - large, the rest - in medium-sized companies.

The obtained data were analysed through the SPSS 21 software. Descriptive statistics and crosstabulation were used for data analysis. The reliability of the questionnaire was screened using Cronbach's alpha coefficient using the SPSS program, varied from 0.648 to 0.683 , confirming strong compatibility of the instrument used.

\section{Results and Discussion}

Primarily the segment of jobs where it was possible for the respondents to perform their job duties remotely was identified: $37.9 \%$ of survey participants estimated that their work could not be done in a remote way, but $26.1 \%$ of respondents job duties cannot be performed remotely. Other respondents estimate that the part of work could be done remotely and the other part - in a workplace created by employer. Thus, it can be stated that the majority of respondents $(62.1 \%$ in sum) could perform at least part of their job duties working remotely.

Nevertheless, $26.1 \%$ jobs can be fully remote, only $4 \%$ of respondents prefer to have completely remote job. The majority of respondents $(41.2 \%)$ would like to have the opportunity to mix working from home

Comparison of possible and preferred remote job design, $\%$

Table 1

\begin{tabular}{|l|c|c|}
\hline & Possible & Preferred \\
\hline Yes, $100 \%$ remotely & 26 & 4 \\
\hline $70 \%$ remote $/ 30 \%$ traditional & 4 & 48 \\
\hline $50 \%$ remote $/ 50 \%$ traditional & 14 & 22 \\
\hline $30 \%$ remote $/ 70 \%$ traditional & 10 & 15 \\
\hline No, $0 \%$ of remote work & 38 & \\
\hline
\end{tabular}


Possibility of virtual job design by fields, \%

\begin{tabular}{|l|c|l|c|l|c|}
\hline Finance/Accounting & 67 & Marketing/Advertising & 42 & Service industry & 12 \\
\hline Education/Science & 67 & Agriculture/Environment & 40 & Manufacturing/Industry & 12 \\
\hline IT/Electronics & 60 & Law/Legal Aid & 25 & Administration & 8 \\
\hline Public Relations & 57 & Management & 20 & State and public administration & 0 \\
\hline Transport/Logistics & 57 & Construction/Real Estate & 17 & Security/Rescue/Defence & 0 \\
\hline Telecommunications & 50 & Trade/Sales & 14 & Human resources & 0 \\
\hline Culture/Arts/Entertainment & 47 & Tourism/Hotels/Catering & 13 & & \\
\hline
\end{tabular}

Table 3

The willingness of the study participants to work remotely according to age groups, $\%$

\begin{tabular}{|c|c|c|c|c|c|}
\hline Age group & No willingness & Partly remotely & Flexibly remotely & Fully remotely & Work remotely \\
\hline $16-25$ & 15 & 17 & 43.5 & 15.6 & 8.8 \\
\hline $26-35$ & 14 & 20 & 34 & 12 & 20 \\
\hline $36-45$ & 33.3 & 0 & 44.4 & 11.1 & 11.1 \\
\hline $46-55$ & 25 & 50 & 25 & 0 & 0 \\
\hline 56 and more & 0 & 0 & 100 & 0 & 0 \\
\hline
\end{tabular}

with going to workplace in flexible way (Table 1), $15.6 \%$ - would not like to, and $14.2 \%$ - would like to have remote job. $17.5 \%$ want to work remotely occasionally, $11.4 \%$ currently have remote job place.

The crosstabulation of the data reveals that the majority of the jobs impossible to perform remotely are in service (11.8\%) and trade/sales fields (17.5\%). Only 3 respondents from the service industry and 5 working in trade/sales state that it is possible to perform job duties from a distance and several respondents believe that it is possible to perform work duties in mixed way.

According to those working in finance/accounting, education/science, information technology/ electronics, public relations, transport/logistics, telecommunications, culture/arts/entertainment, marketing/advertising, agriculture/environment, it is possible to perform their job duties from distant locations in general. Only in fields of state and public administration, security/rescue/defence, and human resources it is not possible to work remotely (Table 2):

Respondents used to be working from remote locations: 5 respondents from marketing/advertising, 4 - from culture/arts/entertainment, 4 - from public relations, 4 - from trade/sales, 1 - from finance/accounting, 1 respondent each was in IT/ electronics, services, construction/real estate, health/ social security, education/science, and agriculture/ environment fields.

Depending on the age distribution of the respondents, only respondents from the 16-25, 2635 , and 36-45 years old groups have remote work experience. Of these, participants of 16-25 years old are the most willing to work from distant locations, while 46 years old and older respondents are much less impressed by the possibility to work remotely (Table 3):

Table 4 analyses the willingness to work remotely by gender: perhaps in need of flexibility performing other duties in personal life and striving for work-life balance, women appear to be more willing to work remotely in flexible way than men, which would prefer more a $100 \%$ remote job.

Also, the willingness to work remotely was analysed by the position held by employees in the company. In the employers/shareholders/selfemployed group willingness to work fully remotely is higher $(23.5 \%)$ than employees $(15.6 \%)$, and $23.5 \%$

Willingness to work remotely by gender, \%

\begin{tabular}{|c|c|c|c|c|c|}
\hline Gender & No willingness & Partly remotely & Flexibly remotely & Fully remotely & Work remotely \\
\hline Women & 8.6 & 20 & 44.3 & 11.4 & 15.7 \\
\hline Men & 16.9 & 12.7 & 35.2 & 19.7 & 15.5 \\
\hline
\end{tabular}


Table 5

Direct/indirect communication throughout the working day with colleagues/managers and clients, \%

\begin{tabular}{|l|c|c|}
\hline & With colleagues/managers & With clients \\
\hline Indirect only & 6.6 & 15.2 \\
\hline Indirect most of the time & 9.5 & 16.6 \\
\hline $50 \%$ indirect, 50\% direct & 17.5 & 17.5 \\
\hline Direct most of the time & 38.4 & 23.7 \\
\hline Direct only & 28.0 & 27.0 \\
\hline
\end{tabular}

Encountering remote job design by the size of the company, $\%$

Table 6

\begin{tabular}{|l|c|c|c|c|}
\hline & Micro-size & Small & Medium & Large \\
\hline Communicating with managers/colleagues/clients abroad & 42.3 & 25.8 & 33.3 & 35.7 \\
\hline Communicating with managers/colleagues/clients in Lithuania & 54.9 & 43.5 & 41.7 & 54.8 \\
\hline Cooperating with partners or suppliers operating abroad & 36.6 & 25.8 & 19.4 & 23.8 \\
\hline Cooperating with partners or suppliers operating in Lithuania & 49.3 & 45.2 & 33.3 & 35.7 \\
\hline
\end{tabular}

of employers/shareholders/self-employed are used to work remotely all the time, while only $11.4 \%$ of employees do the same. The employers/shareholders/ self-employed are less willing to work in mixed flexible way $(23.5 \%)$ when compared with employees (41.2\%).

In sum, the picture of prone to remote job employee by demographic characteristics of the respondents can be drawn: (1) man, (2) 16-25 years of age, (3) freelancer /working in small company, and (4) working in sales or marketing area.

If survey participants are given the opportunity to work remotely from distant locations, the largest part $(62.1 \%)$ will work from home, $41.7 \%$ - flexibly from anywhere and anytime, $25.1 \%$ - when traveling, $12.8 \%$ agree to work remotely during vacation, $1.4 \%$ will find suitable public place, and only $0.9 \%$ of respondents find possible to combine several remote occupations, i.e., to get a higher salary. $15.6 \%$ - do not want to work remotely, but only $3.3 \%$ of them will not categorically work remotely. So, it can be argued that, by getting acquainted with the remote work model, companies start to see the benefits and design remote workplaces, as there is no strong opposition to remote job design.

Assessing the use of indirect communication channels used in companies when working, in communication with colleagues and managers most respondents use telephone (86.3\% of respondents), e-mail (70.1\%), messages $(32.7 \%)$, specific software $(32.2 \%)$, video conferencing $(17.1 \%)$, so, remote job design for them would not be an obstacle to communicate, but $32.2 \%$ of respondents communicate with managers and colleagues only directly face-to-face.
When compared, more respondents interact indirectly with clients than with colleagues or managers at work. Most respondents communicate only a small part of their working time indirectly with colleagues/managers (38.4\% of respondents) (Table 5 ), and the smallest part of respondents do not have any direct contact with colleagues/managers during work $(6.6 \%)$. Many respondents $(27 \%)$ communicate with customers only directly at the workplace and $23.7 \%$ - have a small part of indirect communication with clients.

Explaining where the respondents face the conditions of remote job (Figure 10), 49.3\% face it when communicating with managers/colleagues/ clients living in another Lithuanian city, fewer $(42.7 \%)$ - in cooperation with partners or suppliers operating in Lithuania, $34.6 \%$ communicates with managers/colleagues/clients working abroad, and $28.0 \%$ cooperate with other companies or suppliers abroad. It shows the availability of remote job design even working with inner market, as well as it can help to reduce the cost of business trips abroad.

Analysing remote job design considering the size of the company, it can be stated that indirect communication with managers/colleagues/clients/ partners/suppliers from another Lithuanian city or abroad is most relevant for small companies when compared to large ones (Table 6). Thus, remote job design can be suggested firstly for smaller companies in order to assure all needed infrastructure and help of professionals they cannot afford to hire at the moment.

The most acceptable remote work schedule for survey participants is flexible one, when employee can choose the right ratio of remote work to traditional 
working hours $(47.4 \%)$. The lowest number of survey participants $(4.3 \%)$ was in favour of all 8 hours of remote work, as well as only $14.7 \%$ would like to work all 8 working hours at the employers' guaranteed workplace. $22.3 \%$ of the respondents would work virtually less of their working time, while $11.4 \%$ would work most of their working hours from distant location. Therefore, it can be argued that flexible remote job design could be implemented in the majority of companies in order to reduce costs and raise job satisfaction, as well as employer attractiveness.

However, most of the participants agreed with the statement that the results of working remotely depend on self-discipline (2,66 points from 3 ) and that it would be useful to develop remote jobs in distant locations (2.38 from 3), especially when the lower costs (2.23 from 3 ) and convenience avoiding commuting (2.22 from 3 ) are considered. Most of the respondents does not avoid the use of indirect modern ways of communication (2.10 from 3 ), they even feel less stressed when the formal communication and clothing style is not remotely needed (2.09 from 3) and feel less tension and competition between team members (2.02 from 3).

The main benefits of remote job design identified by respondents are: workplace cost savings (71.6\%), savings in money and time $(71.1 \%$ and $67.3 \%$ respectively), convenience $(57.3 \%)$, although the promotion of new opportunities/innovations in companies and the growth of mobility $(37.4 \%$ and $39.8 \%$ respectively), quick response in the process (29.9\%), faster information transfer $(24.2 \%)$, personal development $(23.7 \%)$, efficiency $(15.6 \%)$, accuracy and clarity of information (11.8\%) are not considered as strengths of remote job design.

Barriers to remote job design appeared to be quite low: difficulties to concentrate (for $30 \%$ of respondents), the need for direct contact with both clients $(36.0 \%)$ and colleagues $(28.0 \%)$, difficulties to understand the information $(21.8 \%)$, lack of experience $(27.0 \%)$, only $16.1 \%$ named the hostile attitude of the managers against remote job in Lithuanian companies, as well as insignificance of factors related to internet connection, working with ICT and e-devices is revealed.

\section{Conclusions}

The most important factors determining the emergence of remote job design are globalization, growth, and acceleration of quality of life, emergence of knowledge society and economy, growth of population mobility and evolution of information and communication technologies. The characteristics of remote job design differ from traditional work in the form of cooperation and workplace, but there are also similarities: the pursuit of organizational goals, communication (indirect) to perform the task correctly, organizational attitudes and more than one working individual.

The employees of Lithuanian companies recognize the benefits of remote job design and would like to work remotely in flexible way for the most, where and when it is needed, at least in a part of their work time. Nevertheless, it is believed that in some areas remote job design application is completely impossible.

Managers in Lithuanian companies do not oppose remote job design, but when working remotely it would be difficult to concentrate and communicate with clients or colleagues and maintain fulfilment of social needs at work; therefore, initial actions on remote job coordination systems and preparing as well as motivating employees to perform work in a timely and productive manner are essential. This would lead them to greater operational efficiency. The remote job design in Lithuanian companies would encourage the implementation of innovations, modernization of workplaces in Lithuania, which would be cheaper and more convenient for the companies and their employees.

Remote job design reveals its benefits in a global environment, where it is possible to work remotely in the same country, as well as successfully collaborate with foreign companies using ICT. Remote workplaces enable companies to hire the best professionals as global talents regardless of where they live. Remote work is also useful for developing business activities in other country without living there. As technology speeds up the transfer of required information, more attention can be paid to reduce the cost of commuting to employers and employees. Remote job design in Lithuanian companies would be effective in terms of cost reduction and employee convenience, as well as useful in cooperation with foreign companies or partners in different cultures. Thus, flexible remote job should be seen not as an exception for the members of the organization, but as reducing costs in the company, increasing the productivity of the organization and job satisfaction of employees.

\section{References}

Arnow-Richman, R. (2020). Is there an individual right to remote work? A private law analysis. ABA Journal of Labor \& Employment Law, 2156480935 (1).

Avdeeva, E.A., Davydova, T.E., \& Shulgin, A.V. (2020). About the prospects of remote work, foreign experience and Russian trends. FES: Finance, Economy, Strategy, 17(4/5), 20-25. 
Calvo, A.J. (2010). Where's the remote? Face time, remote work, and implications for performance management. Cornell HR Review.

Charalampous, M., Grant, Ch.A., Tramontano, C., \& Michailidis, E. (2019). Systematically reviewing remote e-workers' well-being at work: a multidimensional approach. European Journal of Work \& Organizational Psychology, 28(1), 51-73. DOI: 10.1080/1359432X.2018.1541886.

Choudhury, P., Foroughi, C., \& Larson, B. (2021). Work-from-anywhere: The productivity effects of geographic flexibility. Strategic Management Journal, 42(4), 655-683. DOI: 10.1002/smj.3251.

Cvmarket.lt. (2017). Dirbti namie lietuviams trukdo tai, kas amerikiečiams padeda (Lithuanians are hindered from working at home by what helps Americans). Retrieved March 11, 2021, from https://www.cvmarket. lt/karjeros-centras/naujienos-ir-tyrimai/dirbti-namie-lietuviams-trukdo-tai-kas-amerikieciams-padeda. (in Lithuanian).

da Silva Abbad, G., Legenti, J., Damascena, M., Miranda, L., Feital, C., \& Rabelo Neiva, E. (2019). Percepciones de teletrabajadores y trabajadores presenciales respecto del diseño del trabajo (Perceptions of teleworkers and face-to-face workers about work design). Revista Psicologia. Organizacoes e Trabalho, 19(4), 772780. DOI: 10.17652/rpot/2019.4.17501 (in Portugese).

Derks, D., \& Bakker, A. (2010). The impact of e-mail communication on organizational life. Cyberpsychology: Journal of Psychosocial Research on Cyberspace, 4(1).

Duarte, D.L., \& Snyder, N.T. (2006). Mastering virtual teams: strategies, tools and techniques that succeed. Jossey-Bass.

Duoba, K., \& Savaneviciene, A. (2010). Organizacijų virtualumo raiška Lietuvoje (Expression of organizational virtuality in Lithuania). Economics \& Management, 15, 465-470 (in Lithuanian),

Duoba, K. (2009). Organizaciju virtualumo raiška ịvairiose Lietuvos ekonominès veiklos rūšyse : disertacija (Expression of organisational virtuality in different Lithuanian economic sectors). doctoral thesis. Kaunas: KTU. (in Lithuanian).

Eurofund. (2017). Working anytime, anywhere: The effects on the world of work. Retrieved March 11, 2021, from https://www.eurofound.europa.eu/sites/default/files/ef_publication/field_ef_document/ef1658en.pdf.

Fonner, K.L., \& Roloff, M.E. (2010). Why teleworkers are more satisfied with their jobs than are office-based workers: When less contact is beneficial. Journal of Applied Communication Research, 38, 336-361. DOI: 10.1080/00909882.2010.513998.

Gajendran, R.S., \& Harrison, D.A. (2012). The good, the bad, and the unknown about telecommuting: Metaanalysis of psychological mediators and individual consequences. Journal of Applied Psychology, 92(6), 1524-1541. DOI: 10.1037/0021-9010.92.6.1524.

Gallacher, G., \& Hossain, I. (2020). Remote work and employment dynamics under COVID-19: Evidence from Canada. Canadian Public Policy. 2020, Vol. 46 Issue S1, p. S44-S54. 11p. DOI: 10.3138/cpp.2020-026.

Gallup. (2017). In U.S., telecommuting for work climbs to 37\%. Retrieved March 11, 2021, from https://news. gallup.com/poll/184649/telecommuting-workclimbs.aspx.

Garrett, R.K., \& Danziger, J.N. (2007). Which telework? Defining and testing a taxonomy of technologymediated work at a distance. Social Science Computer Review, 25(1), DOI: 10.1177/0894439306293819.

Gibson, C.B., \& Gibbs, J.L. (2006). Unpacking the concept of virtuality: The effects of geographic dispersion, electronic dependence, dynamic structure, and national diversity on team innovation. Administrative Science Quarterly September, 51(3), 451-495. DOI: 10.2189/asqu.51.3.451.

Gigi, G.S., \& Sangeetha, J. (2020). Impact of remote working on employees in IT industry. Journal of Contemporary Issues in Business \& Government, 26(2), 537-544. DOI: 10.47750/cibg.2020.26.02.072.

Grant, Ch.A., Wallace, L.M., \& Spurgeon, P.C. (2013). An exploration of the psychological factors affecting remote e-worker>s job effectiveness, well-being and work-life balance. Employee Relations, 35(5), 527-546. DOI: 10.1108/ER-08-2012-0059.

Greve, A., \& Salaff, J. (2008). Tele-work as knowledge exchange: Can technology support social relations. The Journal of eWorking, 2(2), 95-121.

Grincevičienè, N. (2020). Nuotolinio darbo naudojimo intensyvumo poveikis darbuotojų darbo ir asmeninio gyvenimo balansui (Impact of intensity of remote work on work-life balance of employees). Buhalterinés apskaitos teorija ir praktika, 21. DOI: 10.15388/batp.2020.16. (in Lithuanian).

Haddon, L., \& Brynin, M. (2005). The character of telework and the characteristics of teleworkers. New Technology, Work and Employment, 20 (1), 34-46. DOI: 10.1111/j.1468-005X.2005.00142.x.

Kaduk, A., Genadek, K., Kelly, E.L., \& Moen, Ph. (2019). Involuntary vs. voluntary flexible work: insights for scholars and stakeholders. Community, Work \& Family, 22(4), 412-442. DOI: 10.1080/13668803.2019.1616532. 
Kantar (2020). Du trečdaliai iš darbdavio tikisi galimybès dirbti nuotoliniu būdu (Two-thirds expect an opportunity to work remotely from an employer). Retrieved March 11, 2021, from http://www.kantar.lt/lt/ news/du_trecdaliai_is_darbdavio_tikisi_galimybes_dirbti_nuotoliniu_budu/(in Lithuanian).

Kardelis, K. (2002). Moksliniu tyrimu metodologija ir metodai (Methodology and methods of scientific research). Kaunas: Judex. (in Lithuanian).

Karis, D., Wildman, D., \& Mané, A. (2016). Improving remote collaboration with video conferencing and video portals. Human-Computer Interaction, 31(1), 1-58. DOI: 10.1080/07370024.2014.921506.

Konradt, U., Schmook, R., \& Malecke, M. (2000). Impacts of telework on individuals, organizations and families: A critical review. International Review of Industrial and Organizational Psychology, 15, 63-100. DOI: $10.1177 / 1529100615593273$.

Morganson, V.J., Major, D.A., Oborn, K.L., Verive, J.M., \& Heelan, M.P.(2010). Comparing telework locations and traditional work arrangements: Differences in work-life balance support, job satisfaction, and inclusion. Journal of Managerial Psychology, 25(6), 578-595. DOI: 10.1108/02683941011056941.

Perez Perez, M., Sanchez, A.M., \& de-Luis, P. (2003). The Organizational Implications of Human Resources Managers' Perception of Teleworking. Personnel Review, 32(6), 733-755. DOI: 10.1108/00483480310498693.

Sarkiunaite, I., \& Gaputiene, I. (2006). Informacinès technologijos kaip darbuotojo pasitenkinimo darbu veiksnys (Information technology as a factor of employee job satisfaction). Informacijos mokslai, 37 , 73-82 (in Lithuanian).

Sarkiunaite, I. (2009). Personalo valdymo procesas virtualioje komandoje (Personnel management process in a virtual team). Ekonomika ir vadyba: aktualijos ir perspektyvos, 2 (15), 277-285. (in Lithuanian).

Walentek, D. (2020). Determinants of the attractiveness of telework before the outbreak of the COVID-19 pandemic. Informatyka Ekonomiczna. Business Informatics, 1(55), 80-95. DOI: 10.15611/ie.2020.1.06.

Wang, B., Liu, Y., Qian, J., \& Parker, Sh.K. (2021). Achieving effective remote working during the COVID-19 pandemic: A Work Design Perspective. Applied Psychology: An International Review, 70(1), 16-59. DOI: 10.1111/apps. 12290 . 